\title{
The Metabolism of Free Amino Acids by Washed Suspensions of the Rumen Ciliate Entodinium caudatum
}

\author{
By G. S. COLEMAN \\ Biochemistry Department, Agricultural Research Council, \\ Institute of Animal Physiology, Babraham, Cambridge
}

(Accepted for publication 30 January 1967)

\begin{abstract}
SUMMARY
Washed suspensions of Entodinium caudatum, grown in vitro, incubated anaerobically in the presence of penicillin and neomycin, incorporated single amino acids into the cell protein without conversion to any other amino acid. The ${ }^{14} \mathrm{C}$-labelled components of the protozoal 'pool' and the medium were also investigated but no extensive catabolism of the amino acids observed. At low external concentrations the amino acids were taken up by an 'active' process, but above a critical concentration the amino acids entered the cell by passive diffusion and they have been divided into two groups depending on whether this critical concentration was approximately $0.0001 \mathrm{~m}$ or $0.001 \mathrm{M}$. The rate of amino acid uptake was not altered by the presence of inert particulate matter. Of the $75 \%$ of the cell volume occupied by liquid, approximately two-thirds was freely available to amino acids.
\end{abstract}

\section{INTRODUCTION}

Although Entodinium caudatum can be grown in vitro in the presence of bacteria on a substrate of rice starch grains and dried grass (Coleman, 1960a) it has so far not proved possible to grow these protozoa in the absence of bacteria (Coleman, 1962). As a result, nothing is known about the amino acid metabolism of axenic rumen Entodiniomorphid protozoa although studies have been made by using protozoa prepared from in vitro cultures (Coleman, 1964a) and from the rumen and washed free from external bacteria. Protozoa from the rumen were used to show that ${ }^{14} \mathrm{C}$ was incorporated from ${ }^{14} \mathrm{C}$-DL-alanine, DL-leucine and DL-valine by Ophryoscolex caudatus (Williams, Davis, Doetsch \& Gutierrez, 1961) and Epidinium ecaudatum (Gutierrez \& Davis, 1962) although with neither organism was the cellular distribution of the incorporated amino acid investigated. Warner (1964) found that rumen protozoa may contain a glutaminase and Abou Akkada \& Howard (1962) with Entodinium caudatum obtained results consistent with this, but found negligible deamination of amino acids or uptake into cellular materials of the amino acids in casein or casein hydrolysate. However, these results were obtained by using non-radioactive methods, which would only detect large differences. In the present studies and those reported previously for glycine (Coleman, 1964a) the metabolism of ${ }^{14} \mathrm{C}$-amino acids has been followed by using washed suspensions of Entodinium caudatum grown under standard conditions in vitro and an attempt made to determine, for 11 amino acids, the products of their metabolism and possible intermediates in this process, the kinetics of their incorporation by the protozoa and the permeability of the protozoa. 


\section{METHODS}

Source of protozoa. The protozoa were grown and 'inoculum cultures' prepared and treated as described by Coleman (1962) except that inoculum cultures were treated each day with $15 \mathrm{mg}$. rice starch and about $10 \mathrm{mg}$. dried grass.

Preparation of protozoa for inoculation. The protozoa were taken from the inoculum cultures after removal of the surface scum and most of the supernatant liquid, and allowed to stand in $9 \times 1$ in. tubes until any grass present had sunk to the bottom. The supernatant fluid containing the protozoa was transferred to centrifuge tubes, the residual grass washed with salt solution B (Coleman, 1960 b) and the washings added to the supernatant fluid. The protozoa were spun down and washed four times in salt solution B on a bucket-head centrifuge for $20 \mathrm{sec}$. from starting; the maximum speed was equivalent to $200 \mathrm{~g}$. The organisms were finally inoculated at a population density of 50,000-250,000/ml. incubation medium.

Incubation conditions for incorporation experiments. Except where otherwise stated the medium consisted of $1 \cdot 8-8.2 \mathrm{ml}$. (chosen so that the final volume was $10 \mathrm{ml}$.) salt solution B (Coleman, $1960 \mathrm{~b}$ ), 0-6.0 ml. water, 0-6.0 ml. double strength salt solution $B$ and $0 \cdot 1-0.5 \mathrm{ml} .{ }^{14} \mathrm{C}$-amino acid autoclaved $\left(115^{\circ}\right.$ for $20 \mathrm{~min}$.), all in a $15 \mathrm{ml}$. centrifuge tube. Standard salt solution contained $6.6 \mathrm{ml}$. salt solution B, $2.2 \mathrm{ml}$. water and the following additions. The concentration was altered by replacing the salt solution by water or the water and salt solution by salt solution of double the normal concentration. Immediately after removal from the autoclave the following additions were made aseptically: $0.2 \mathrm{ml} .1 \%$ L-cysteine hydrochloride (neutralized and Seitz filtered), $0.2 \mathrm{ml} .5 \% \mathrm{NaHCO}_{3}$ (Seitz filtered), $0.4 \mathrm{ml}$. penicillin $\mathrm{G}(25,000$ units $/ \mathrm{ml}$.), 0.4 ml. $1 \%$ neomycin sulphate solution and any other additions. After inoculation the tubes were gassed for $10 \mathrm{sec}$. with $95 \%(\mathrm{v} / \mathrm{v}) \mathrm{N}_{2}+5 \%(\mathrm{v} / \mathrm{v}) \mathrm{CO}_{2}$, sealed with a sterile rubber bung and incubated at $39^{\circ}$. At the end of the experiment the protozoa were centrifuged and washed twice at $200 \mathrm{~g}$ for $30 \mathrm{sec}$. in salt solution B.

Protozoal counts. The number of protozoa was estimated by the method of Coleman (1958). Only those protozoa which showed no signs of disintegration were counted.

Estimation of ${ }^{14} \mathrm{C} .{ }^{14} \mathrm{C}$ in whole protozoa was estimated by washing the organisms with water onto an aluminium disc of area $4.7 \mathrm{~cm} .{ }^{2}$ carrying a disc of lens tissue. The sample was spread by one drop of cetyltrimethylammonium bromide solution $(5 \mathrm{mg}$./ $\mathrm{ml}$.) and fixed by one drop of polyvinyl alcohol $\left(2 \mathrm{mg}\right.$. $/ \mathrm{ml}$.). The disc was dried at $40^{\circ}$ and the ${ }^{14} \mathrm{C}$ estimated by using an automatic flow counter (Nuclear-Chicago Corp.) with an efficiency of about $20 \%$. Over 1000 counts at a rate greater than five times background were recorded for all fractions. Determinations were made with less than $0.5 \mathrm{mg}$. of material per $\mathrm{cm}^{2}$ of disc. The amount of amino acid incorporated by protozoa was calculated from the known specific activity (usually $0.001-5 \cdot 0 \mu \mathrm{c} / \mu \mathrm{M}$ ) of amino acid added initially. For the estimation of non-volatile material in the medium $0 \cdot 1-0 \cdot 2 \mathrm{ml}$. was placed on an aluminium disc in the standard manner and then $0 \cdot 1$ $\mathrm{ml}$. $\mathrm{N}-\mathrm{HCl}$ added to remove the volatile material on drying down. To retain volatile compounds on the disc the $\mathrm{HCl}$ was replaced by $0 \cdot 1 \mathrm{ml} .0 \cdot 1 \mathrm{~N}-\mathrm{NaOH}$ and the quantity present measured as the difference between the radioactivity determined in the presence of $\mathrm{HCl}$ and $\mathrm{NaOH}$. As measurements of radioactivity on discs on which tracer quantities of theoretically non-volatile compounds such as ${ }^{14} \mathrm{C}$-L-leucine had been plated out were lower after addition of $\mathrm{HCl}$ than after $\mathrm{NaOH}$, the production of 
volatile materials from amino acids was always corrected for 'volatile material' present initially and on incubation in the absence of protozoa. To determine the relative ${ }^{14} \mathrm{C}$ contents of spots on a chromatogram a thin mica end-window GM tube was placed directly on the spot, the position of which had been determined by radioautography.

Fractionation of organisms. The protozoa after harvesting, washing as described above and resuspension in $2 \mathrm{ml}$. of water in a $5 \times \frac{1}{2}$ in. thin-walled test-tube were broken by immersion of the tube to the depth of liquid in the tube in a $80 \mathrm{kc} / \mathrm{sec}$. $40 \mathrm{~W}$. ultrasonic cleaning bath (KG 80/1, manufactured by Kerrys' of Chester Hall Lane, Basildon, Essex) for $15 \mathrm{sec}$. The homogenate was then centrifuged at $7000 \mathrm{~g}$ for $20 \mathrm{~min}$. The supernatant liquid from this centrifugation is hereafter referred to as the 'broken cell supernatant fluid' and the pellet after washing once in water as the 'broken cell pellet'. This latter fraction contained all the viable bacteria in the homogenate.

These two fractions were further fractionated by a method based on that of Roberts et al. (1955). The fraction was treated with $5 \%$ trichloroacetic acid (TCA) and allowed to stand at $4^{\circ}$ for $30 \mathrm{~min}$. The precipitate was centrifuged down and washed once with $5 \%$ TCA. The supernatant fluid and the washing formed the "cold TCA soluble fraction'. The precipitate was then extracted with $75 \%(\mathrm{v} / \mathrm{v})$ ethanol in water at $40^{\circ}$ for $30 \mathrm{~min}$. The residue was centrifuged down and the supernatant fluid formed the alcohol-soluble fraction. The precipitate was then extracted twice with $5 \%$ TCA at $100^{\circ}$ for $30 \mathrm{~min}$. The supernatant fluids formed the 'hot TCA soluble or nucleic acid fraction'. The residue after further washing, once with acidified ethanol and once with ether, formed the 'residual protein fraction'. The TCA was removed from fractions by washing three times with ether before plating out for the estimation of ${ }^{14} \mathrm{C}$. The alcohol-soluble fraction was further fractionated by the addition of equal quantities of water and ether and the two layers so obtained were separated. The aqueous layer after washing once with ether formed the 'alcohol soluble protein fraction' and the ether layer plus the washing formed the 'lipid fraction'.

The complete acid hydrolysis of any fraction was done by heating to $105^{\circ}$ in $6 \mathrm{~N}-$ $\mathrm{HCl}$ for $16 \mathrm{hr}$ in a sealed tube. At the end of this period the tube was cooled and opened and the acid removed on a boiling water bath in a current of air.

Paper chromatography. The following solvents were used: A, sec-butanol+formic acid + water $\left(70+10+20\right.$, by vol.) at $30^{\circ} ; \mathrm{B}$, sec-butanol +formic acid + water $(70+10+20$, by vol. $)$ at $4^{\circ} ; \mathrm{C}$, sec-butanol + formic acid + water $(60+20+20$ by vol. $)$ at $4^{\circ}$; D, phenol + ammonia (sp.gr. $\left.0 \cdot 880\right)+$ water $(80 \mathrm{~g} .+0 \cdot 3 \mathrm{ml} .+20 \mathrm{ml}$.); E, $n$ propanol+ethyl acetate + water $(24+13+7$, by vol.); F, ethanol+ammonia (sp.gr. $=0.880)+$ water $(80+5+15$, by vol.); G, $n$-butanol +acetone + water +diethylamine $(10+10+5+2$, by vol.; Hardy, Holland \& Nayler, 1955); H, $n$-butanol saturated with $1.5 \mathrm{~N}-\mathrm{NH}_{4} \mathrm{OH} ; \mathrm{J}, n$-butanol saturated with $1.5 \mathrm{~N}-\mathrm{NH}_{4} \mathrm{OH} / 1.5 \mathrm{~N}$ $\left(\mathrm{NH}_{4}\right)_{2} \mathrm{CO}_{3}$ buffer; $\mathrm{K}, n$-butanol + cyclohexane + propylene glycol + water + ammonia (sp.gr. $=0 \cdot 880)+$ morpholine $(30+30+10+3 \cdot 5+0 \cdot 7+0 \cdot 07$, by vol.; Guillaume $\&$ Osteux, 1955).

Protein hydrolysates were chromatographed in two dimensions in solvents A and D (Roberts et al. 1955).

Identification of ${ }^{14} \mathrm{C}$-labelled compounds in the medium and the protozoal 'pool'. As many of these compounds were present in small amounts and were often not detectable 
on chromatograms by the use of conventional chemical sprays, their composition was elucidated by the following methods. The medium or the 'cold TCA-soluble fraction', after removal of the TCA with ether, was treated with Zeo Karb $225\left(\mathrm{H}^{+}\right)$to remove free amino acids. The supernatant fluid was neutralized with $8 \%(\mathrm{w} / \mathrm{v}) \mathrm{Ba}(\mathrm{OH})_{2}$ and the precipitate centrifuged down. If the presence of ${ }^{14} \mathrm{C}$-labelled volatile acids was suspected, this supernatant fluid was evaporated to dryness in vacuum and the residue fractionated by paper chromatography. Otherwise the supernatant fluid was run through a column of Dowex $2\left(\mathrm{OH}^{\prime}\right)$ which was then washed with water and any acidic compounds eluted with $\mathrm{N}-\mathrm{HCl}$. The eluates were evaporated to dryness in vacuum and the residues chromatographed. The basic compounds were eluted from the Zeo Karb 225 with $\mathrm{N}-\mathrm{NH}_{4} \mathrm{OH}$ and the eluate evaporated to dryness in vacuum.

The residues obtained from the resins as described above were chromatographed initially in solvent $\mathrm{A}$ and then the ${ }^{14} \mathrm{C}$ compounds present (as detected by radioautography) eluted and re-chromatographed before and after hydrolysis in $6 \mathrm{~N}-\mathrm{HCl}$ in solvents $\mathrm{A}-\mathrm{K}$ and shown to run with the same $R_{F}$ value as marker compounds. The identity of ${ }^{14} \mathrm{C}$ compounds provisionally identified by chromatography was confirmed by the 'fingerprint' technique of Roberts et al. (1955). For this method the unknown ${ }^{14} \mathrm{C}$ compound, in tracer quantities only, was mixed with a relatively large amount of the ${ }^{12} \mathrm{C}$ form of the compound with which it had been identified and the whole chromatographed in two dimensions. The ${ }^{14} \mathrm{C}$ spot was then detected by radio-autography and the carrier compound by a convenient chemical method. When the tracer and carrier compound are the same, then the pattern of the radio-autogram must agree in every detail with the pattern of the chemical spray.

The volatile acids produced during the metabolism of $\left[\mathrm{U}-{ }^{14} \mathrm{C}\right]-\mathrm{L}-$-alanine were removed from the medium by steam distillation and then the distillate was neutralized, evaporated to dryness in vacuo and the residue chromatographed in solvent $\mathrm{K}$ which separated formic, acetic and propionic acids. The acidic material produced during the metabolism of $\left[\mathrm{U}-{ }^{14} \mathrm{C}\right]$ phenylalanine was extracted from the acidified medium with ether.

Chemicals. $N$-acetyl-DL-alanine and $N$-acetyl-DL-leucine were supplied by L. Light and Co. Ltd. Colnbrook. $N$-acetyl-L-glutamic acid was supplied by the British Drug Houses Ltd, Poole. $N$-formyl L-glutamic acid and $\alpha$ - $N$-formyl L-glutamine were synthesized by the methods of Tabor \& Mehler (1954) and Borek \& Waelsch (1953) respectively and $N$-formyl-DL-alanine by the method of Greenstein \& Winitz (1961). The melting points and equivalent weights, obtained by titration with $\mathrm{NaOH}$, of these last three compounds agreed with the values given in the literature.

${ }^{14} \mathrm{C}$-compounds were supplied by the Radiochemical Centre, Amersham, Buckinghamshire. The specific activities of the compounds as supplied were, in $\mu \mathrm{c} / \mathrm{mg}$.; [U-14 C]-L-arginine, 113; [U-14 C]-L-aspartic acid, 226; [U-14C]-L-glutamic acid, 262; $\left[\mathrm{U}-{ }^{14} \mathrm{C}\right]-\mathrm{L}-$-isoleucine, 183; [U-14 C]-L-leucine, 320; [U-14 C]-L-lysine, 72; [U-14 C]-Lphenylalanine, 41 ; [U--14 C]-L-proline, 110; [U-14 C]-L-serine, $215\left[; \mathrm{U}^{14} \mathrm{C}\right]-\mathrm{L}-\mathrm{valine}, 59$.

\section{RESULTS}

Washed suspensions of Entodinium caudatum prepared from growing cultures and incubated anaerobically in the presence of penicillin and neomycin incorporated ${ }^{14} \mathrm{C}$ from ${ }^{14} \mathrm{C}$-labelled amino acids for $5 \mathrm{hr}$. Figure 1 shows the results obtained with 
[U-14 $\mathrm{C}$ ]-L-leucine. The amino acids could be divided into two groups depending on their rate of uptake by the protozoa when this was measured at an amino acid concentration of $0.01 \mathrm{~mm}$ in the presence of about 50,000 protozoa $/ \mathrm{ml}$. suspended in salt solution at $60 \%$ of the standard concentration. The amino acids of group 1 which contained alanine, arginine, aspartic acid, glutamic acid and serine were incorporated at a rate of around 0.3-0.5 $\mu \mathrm{g} . / 10^{7}$ protozoa $/ 5 \mathrm{hr}$, and those of group 2 which contained isoleucine, leucine, methionine, phenylalanine, proline and valine at a rate of 3.0-4.0 $\mu \mathrm{g}$. $/ 10^{7}$ protozoa $/ 5 \mathrm{hr}$. These results compare with a rate of $4.0 \mu \mathrm{g}$. $/ 10^{7}$ protozoa $/ 5 \mathrm{hr}$ for glycine (Coleman, 1964a) under the same conditions.

The uptake of individual ${ }^{14} \mathrm{C}$-amino acids present at $0.01 \mathrm{~mm}$ was also measured in the presence of 17 other ${ }^{12} \mathrm{C}$-amino acids at $0.002 \mathrm{M}$. The complete 18 amino acid mixture contained L-alanine, L-arginine, L-aspartic acid, L-cysteine, L-glutamic acid, glycine, L-histidine, L-isoleucine, L-lysine, L-methionine, L-phenylalanine, L-proline, L-serine, L-threonine, L-tryptophan, L-tyrosine and $\mathrm{L}$-valine and the ${ }^{12} \mathrm{C}$-form of the amino acid to be tested was omitted in each experiment. The addition of the $17^{12} \mathrm{C}$ amino acids had a variable effect; for example, they increased the incorporation of ${ }^{14} \mathrm{C}$-alanine by $300 \%$, decreased that of ${ }^{14} \mathrm{C}$-leucine by $75 \%$ and had no effect on the uptake of ${ }^{14} \mathrm{C}$-glutamic acid. A possible explanation of these results is provided below in the studies of the effects of individual ${ }^{12} \mathrm{C}$-amino acids on the incorporation of ${ }^{14} \mathrm{C}$ amino acids.

\section{Effect of amino acid concentration}

At low amino acid concentrations (below $10^{-3} \mathrm{M}$ ) the rate of uptake of a group 2 amino acid was always greater than that for a group 1 amino acid, but over a certain critical concentration the rates for the two groups became similar. Above this concentration any increase in the amino acid concentration produced a proportionate increase in the amount of amino acid incorporated by the protozoa, i.e. the proportion of the original amino acid that was incorporated was independent of concentration. This is shown in Fig. 2, where the results are plotted as reciprocal of the ${ }^{14} \mathrm{C}$ incorporated over $3 \mathrm{hr}$ against the reciprocal of the substrate concentration for serine (group 1) and leucine (group 2). It is apparent that there is a sharp break in both curves and that for serine occurs at a much lower concentration than that for leucine. Extrapolation of the right-hand part of the curve to the ordinate measures the maximum rate of uptake for this reaction at infinite amino acid concentration. The left-hand part of the curve always passes near to or through the origin. The results for all the amino acids tested are given in Table 1 . This shows that the maximum rate for the right-hand part of the curve and the position of the break are much higher for group 2 than group 1 amino acids but that the slope of the left-hand part is similar for all amino acids. These results suggest that at high concentrations amino acids passed into the organisms by passive diffusion whereas at low concentrations below the break in the curve uptake could have been dependent on metabolic processes. The existence of a passive uptake is supported by the observations $(a)$ that the proportion of the amino acid present, that was taken up, was independent of concentration and $(b)$ that at infinite amino acid concentration an infinite amount would have been incorporated as shown by passage of the curves through the origin. 


\section{Effect of salt concentration on amino acid uptake}

Figure 3 shows that within the limits of the salt concentration that the protozoa would tolerate without dying and at $0.01 \mathrm{~mm}$ amino acid concentration, there was little effect on the rate of uptake of group 1 amino acids but that the incorporation of

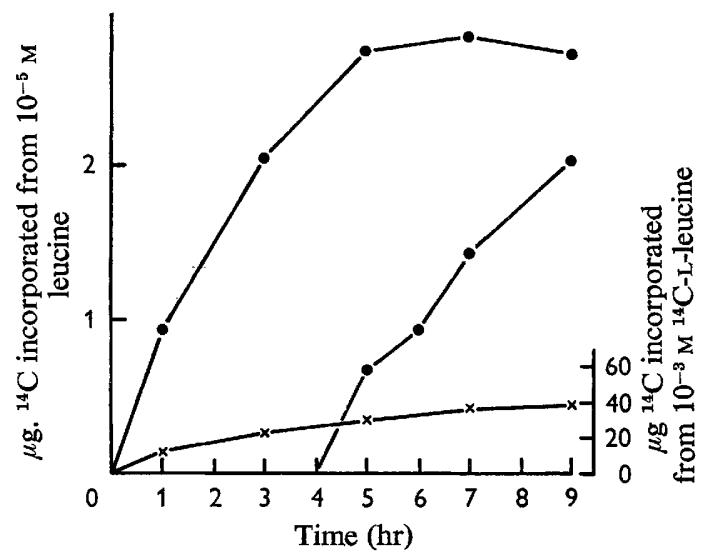

Fig. 1

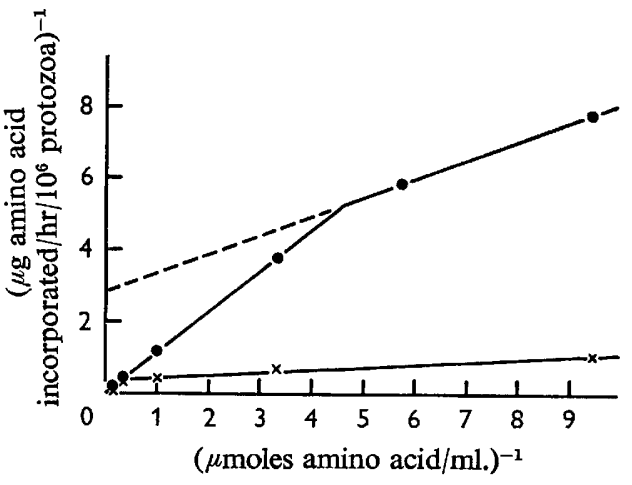

Fig. 2

Fig. 1. Incorporation of $10^{-5} \mathrm{M}(-)$ or $10^{-3} \mathrm{M}(\times-\times)$ [U-14 C]-L-leucine added initially or after $4 \mathrm{hr}$ by $10^{7}$ Entodinium caudatum incubated anaerobically in the presence of 1000 units penicillin $+400 \mu \mathrm{g}$. neomycin sulphate $/ \mathrm{ml}$.

Fig. 2. Effect of substrate concentration on the incorporation of $\left[\mathrm{U}^{14} \mathrm{C}\right]-\mathrm{L}-$ serine $(-)$ and $\left[\mathrm{U}-{ }^{14} \mathrm{C}\right] \mathrm{L}$-leucine $(x-x)$ by Entodinium caudatum $(48,000 / \mathrm{ml}$.) in the presence of 1000 units penicillin $+400 \mu \mathrm{g}$. neomycin sulphate $/ \mathrm{ml}$.

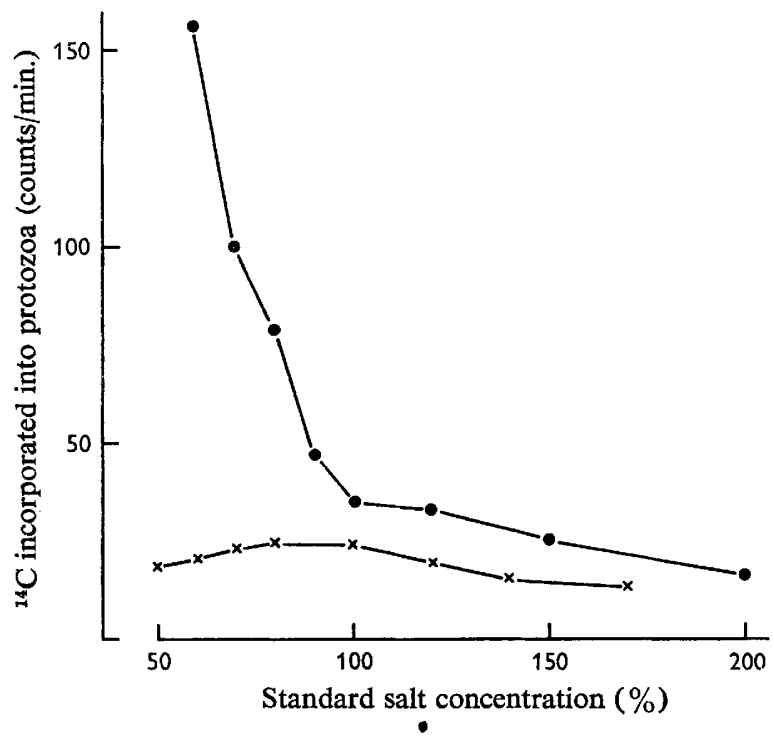

Fig. 3. Effect of salt concentration on the incorporation of ${ }^{14} \mathrm{C}$ from ${ }^{14} \mathrm{C}$-labelled group 1 $(x-x)$ or group $2(-0)$ amino acids (see text) by Entodinium caudatum incubated anaerobically in the presence of 1000 units penicillin $+400 \mu \mathrm{g}$. neomycin sulphate $/ \mathrm{ml}$. 
group 2 amino acids was markedly increased at low salt concentrations. The maximum velocity for the active uptake of phenylalanine (group 2) at $200 \%$ of standard salt concentration was only $20 \%$ of that at $50 \%$ standard salt and the position of the break in the reciprocal uptake curve decreased from $0.003 \mathrm{M}$ at $50 \%$ to $0.0017 \mathrm{M}$ at $200 \%$ standard salt concentration.

\section{Table 1. The incorporation of amino acids by Entodinium caudatum}

Protozoa were incubated anaerobically at a population density of about $50,000 / \mathrm{ml}$. in salt solution containing 1000 units penicillin and $400 \mu \mathrm{g}$. neomycin sulphate $/ \mathrm{ml}$. in the presence of $10^{-6}-2 \times 10^{-2} \mathrm{M}$ of each amino acid labelled with ${ }^{14} \mathrm{C}$ for $4 \mathrm{hr}$. The protozoa were then harvested, washed and their ${ }^{14} \mathrm{C}$ content determined. The quantity of amino acid incorporated was calculated from the known specific activity of the amino acid at each concentration tested, and the reciprocal of this value plotted against the reciprocal of the substrate concentration (Fig. 2). From these curves was calculated the maximum velocity of the active process (by extrapolation of the right-hand part of the curve to the ordinate), the position of the break in the curve and the slope of the left-hand part.

\begin{tabular}{|c|c|c|c|c|}
\hline Amino acid & Group & $\begin{array}{c}\text { Maximum } \\
\text { velocity } \\
\left(\mu \mathrm{g} . / \mathrm{hr} / 10^{\mathbf{6}}\right. \\
\text { protozoa })\end{array}$ & $\begin{array}{c}\text { Break at } \\
\text { (mM) }\end{array}$ & $\begin{array}{c}\text { Slope of } \\
\text { left-hand curve } \\
\left(10^{6} \text { protozoa } \times \mathrm{hr} / \mathrm{ml} .\right)\end{array}$ \\
\hline L-Alanine & 1 & $0 \cdot 21$ & $0 \cdot 12$ & $1.3 \times 10^{3}$ \\
\hline L-Arginine & 1 & 0.73 & 0.22 & $2.2 \times 10^{3}$ \\
\hline L-Aspartic acid & 1 & 0.09 & $0 \cdot 10$ & $1.8 \times 10^{3}$ \\
\hline L-Glutamic acid & 1 & 0.09 & $0 \cdot 20$ & $4.2 \times 10^{3}$ \\
\hline L-Isoleucine & 2 & $3 \cdot 6$ & $1 \cdot 5$ & $1.0 \times 10^{3}$ \\
\hline L-Leucine & 2 & $2 \cdot 88$ & $2 \cdot 5$ & $1.2 \times 10^{3}$ \\
\hline L-Lysine & . & $0 \cdot 12$ & 0.086 & $1.6 \times 10^{3}$ \\
\hline L-Phenylalanine & 2 & 1.45 & $3 \cdot 0$ & $3.3 \times 10^{3}$ \\
\hline L-Proline & 2 & $1 \cdot 24$ & $1 \cdot 2$ & $1.3 \times 10^{3}$ \\
\hline L-Serine & 1 & $0 \cdot 35$ & $0 \cdot 22$ & $1.2 \times 10^{3}$ \\
\hline L-Valine & 2 & 1.70 & $2 \cdot 0$ & $1.7 \times 10^{3}$ \\
\hline
\end{tabular}

\section{Effect of $\mathrm{pH}$ value on amino acid incorporation}

Figure 4 shows the effect of variations in the $\mathrm{pH}$ value of the standard salts medium on the uptake of ${ }^{14} \mathrm{C}$-isoleucine (group 2) at low and just above standard salt concentrations. At low salt concentration the optimum $\mathrm{pH}$ value was $6 \cdot 8-7 \cdot 0$ but at the higher salt concentration there was no clearly defined optimum $\mathrm{pH}$ value.

\section{Effect of particulate matter on the incorporation of amino acids}

Holter (1965) showed that in Amoeba proteus which was taking up protein particles from the medium by pinocytosis only $5 \%$ of the liquid in which the protein was suspended was taken up at the same time. Since Entodinium caudatum rapidly engulfs bacteria (Coleman, 1964b) and other particulate matter the effect of these materials on the incorporation of ${ }^{14} \mathrm{C}$-amino acids from the medium was examined. Of the substances tested $0.02 \%$ rice starch grains, $0.1 \%$ casein, $10^{8}$ polystyrene particles $/ \mathrm{ml}$. (approximately $2 \mu$ in diameter) had no effect, whereas heated Escherichia coli and $10^{8}$ sulphonated-polystyrene particles $/ \mathrm{ml}$. stimulated ${ }^{14} \mathrm{C}$-leucine uptake by $10-40 \%$ and live $E$. coli uptake by up to $100 \%$. In the presence of the live $E$. coli as much or more ${ }^{14} \mathrm{C}$ was found in the bacteria as in the protozoa after incubation for $3 \mathrm{hr}$ but none was bound to the other particulate materials after these had been washed twice in salt solution. Nevertheless, since polystyrene particles stimulated when sulphonated but not when unsubstituted, it is possible that some amino acid molecules may be loosely 
bound to the negatively charged sulphonyl groups even at $\mathrm{pH} 7$ and be transported into the organism. It is considered that particulate matter per se does not increase the rate of amino acid incorporation, but that in the presence of charged particles or complicated particles such as bacteria, live or dead, some additional amount of amino acid was taken up associated with the particles.

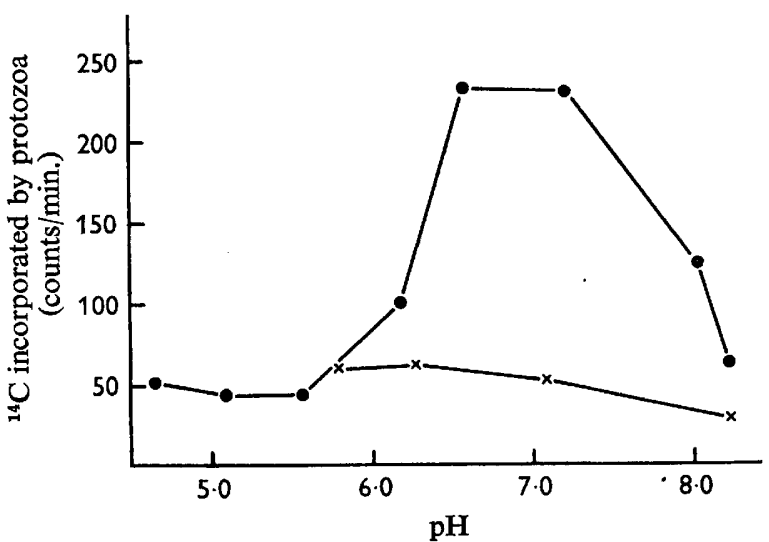

Fig. 4

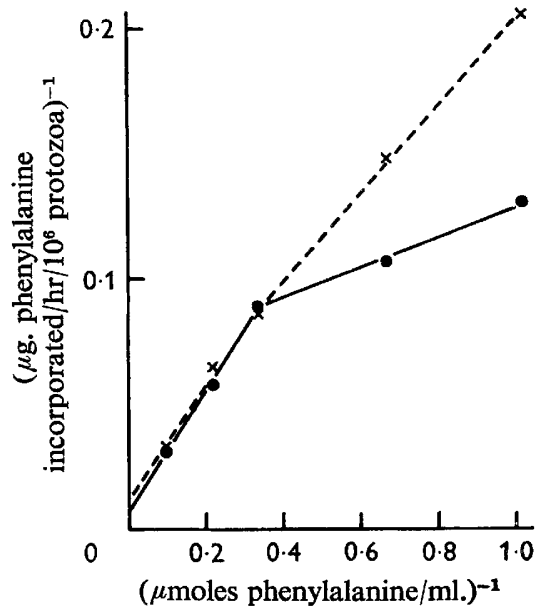

Fig. 5

Fig. 4. Effect of $\mathrm{pH}$ value on the incorporation of $\left[\mathrm{U}-{ }^{14} \mathrm{C}\right]-\mathrm{L}-$ isoleucine $(0 \cdot 2 \mu \mathrm{g}$. and 40,000 counts $/ \mathrm{min}$.) by Entodinium caudatum $\left(4.4 \times 10^{4} / \mathrm{ml}\right.$.) in the presence of 1000 units penicillin $+400 \mu \mathrm{g}$. neomycin sulphate $/ \mathrm{ml}$. Duration of experiment $3 \mathrm{hr}$.,$- 50 \%$ of standard salt concentration; $x-\times, 120 \%$ of standard salt concentration.

Fig. 5. Effect of substrate concentration on the incorporation of $\left[\mathrm{U}-{ }^{14} \mathrm{C}\right]-\mathrm{L}-$ phenylalanine by Entodinium caudatum incubated anaerobically in the presence of 1000 units penicillin $+400 \mu \mathrm{g}$. neomycin sulphate/ml. and in the presence $(x---x)$ or absence $(0-0)$ of 0.01 M-DL-p-fluorophenylalanine.

\section{Effect of p-fluorophenylalanine on phenylalanine uptake}

If the uptake of amino acids consists of an active and a passive process, then the passive part should be extendable by the inhibition of the active process. In an attempt to find a suitable inhibitor the effect of various amino acid analogues on the uptake of their parent amino acids was investigated. $p$-Fluorophenylalanine was found to inhibit the incorporation of ${ }^{14} \mathrm{C}$-phenylalanine and at $0.01 \mathrm{M}-\mathrm{DL}-p$-fluorophenylalanine the same proportion of the added phenylalanine was incorporated at all substrate concentrations. Figure 5 is a reciprocal plot of the amount of ${ }^{14} \mathrm{C}$-phenylalanine incorporated in $5 \mathrm{hr}$ against phenylalanine concentration and shows that in the presence of $p$-fluorophenylalanine the discontinuity in the curve was almost completely abolished and that the slope of the curve was that of the passive reaction. Table 3 shows that in the presence of $p$-fluorophenylalanine the incorporation of ${ }^{14} \mathrm{C}$ from ${ }^{14} \mathrm{C}$-phenylalanine into the protozoal protein was markedly decreased.

Gale (1947) showed that it was possible to distinguish between the uptake of amino acids into bacteria by an active or diffusion process by investigating the effect of a $10^{\circ}$ alteration in temperature (the temperature coefficient $=$ rate at $t+10^{\circ} /$ rate at $t^{\circ}$ ). Davson \& Danielli (1952) and Bull (1951) showed that the temperature coefficient for 
a diffusion process should be $1 \cdot 32$, whereas that for an enzymic reaction was usually higher. To determine the temperature coefficient for the incorporation of ${ }^{14} \mathrm{C}$-phenylalanine by Entodinium caudatum the uptake in the presence and absence of $p$-fluorophenylalanine was measured at $30^{\circ}$ and $40^{\circ}$. In the presence of the inhibitor the temperature coefficient was 2.0 at all phenylalanine concentrations, and in the absence of inhibitor it was 3.4 and 1.9 at low and high phenylalanine concentrations, respectively. Although these results give further support to the suggestion that the mechanism of uptake at high phenylalanine concentrations and at all phenylalanine concentrations in the presence of $p$-fluorophenylalanine are similar, all the values for the temperature coefficients were much higher than those of 1.4 and 1.96 found by Gale (1947) for the uptake of lysine and glutamic acid, respectively, by Streptococcus faecalis. A possible explanation of this discrepancy may be found in the observation that at $30^{\circ}$ the protozoa became almost non-motile and formed a tight pellet on the bottom of the tubes. At $30^{\circ}$ the diffusion path for amino acid molecules from the bulk medium into the pellet and then inside the protozoa would certainly be much longer than at $40^{\circ}$ where the protozoa were actively motile and were directing medium into their gastric sacs by organized ciliary activity. This effect of a $10^{\circ}$ alteration in temperature would not occur in bacterial suspensions and hence the temperature coefficient obtained with protozoal suspensions could be larger.

\section{Effect of amino acids on uptake of individual amino acids}

In an attempt to find an explanation for the variable effect of a complete mixture of amino acids on the uptake of individual ${ }^{14} \mathrm{C}$-amino acids the effect of single ${ }^{12} \mathrm{C}$-amino acids at $0.01 \mathrm{M}$ on the incorporation of individual ${ }^{14} \mathrm{C}$-amino acids at $0.01 \mathrm{~mm}$ was investigated. Table 2 shows those amino acids out of L-alanine, L-arginine, L-asparagine, L-cysteine, L-glutamic acid, L-glutamine, glycine, L-isoleucine, L-leucine, L-lysine, L-methionine, L-phenylalanine, L-proline, L-serine, L-threonine and L-valine which decreased or stimulated the incorporation of another amino acid by over $50 \%$. The majority of amino acids altered the incorporation of any particular amino acid by less than $10 \%$. For those experiments in which the effect of ${ }^{12} \mathrm{C}$-L-cysteine was studied the cysteine was omitted from the standard medium and the traces of oxygen removed by bubbling $\mathrm{O}_{2}$-free $\mathrm{N}_{2}$ through the medium for $3 \mathrm{~min}$. It is apparent that only those amino acids which are structurally related to the given ${ }^{14} \mathrm{C}$-amino acid affected its uptake; this suggests that each amino acid may have a specific uptake mechanism. For all the amino acid mixtures listed in Table 2 the effect of the inhibitory amino acids tested at concentrations of the ${ }^{14} \mathrm{C}$-amino acid from 0.01 to $20 \mathrm{~mm}$ but only with the pairs ${ }^{14} \mathrm{C}$-phenylalanine $+{ }^{12} \mathrm{C}$ - $p$-fluorophenylalanine and ${ }^{14} \mathrm{C}$-aspartic acid $+{ }^{12} \mathrm{C}$ asparagine was the incorporation of the ${ }^{14} \mathrm{C}$-amino acid independent of its concentration in the presence of $0.01 \mathrm{M}$ inhibitor. This shows that only with these pairs was the active uptake reaction completely abolished by the inhibitor. However, the aspartic acid/asparagine effect might be an artifact as some of the asparagine was hydrolysed to aspartic acid during the experiment.

\section{Intracellular products of amino acid metabolism}

Table 3 shows the distribution in the major cell fractions of ${ }^{14} \mathrm{C}$ incorporated from ${ }^{14} \mathrm{C}$-phenylalanine and is typical of that for any amino acid of group 2 . Group 1 amino acids gave a similar pattern except that $40-50 \%$ of the ${ }^{14} \mathrm{C}$ was in the cold TCA-soluble 
fraction or cell 'pool'. To determine whether there had been any interconversions between the amino acids, the protein in the broken cell supernatant fluid and in the broken cell pellet were hydrolysed, the amino acids chromatographed on paper in two

Table 2. Inhibition of the incorporation of individual ${ }^{14} \mathrm{C}$-amino acids into Entodinium caudatum by other ${ }^{12} \mathrm{C}$-amino acids

Protozoa were incubated anaerobically at a population density of about $50,000 / \mathrm{ml}$. in salt solution containing 1000 units penicillin and $400 \mu \mathrm{g}$. neomycin sulphate $/ \mathrm{ml}$. in the presence of about $0 \cdot 2 \mu \mathrm{g}$. of individual ${ }^{14} \mathrm{C}$-amino acids for $5 \mathrm{hr}$ in the presence or absence of other ${ }^{12} \mathrm{C}$-amino acids at $0.01 \mathrm{M}$. Only those ${ }^{12} \mathrm{C}$-amino acids which decreased the incorporation of ${ }^{14} \mathrm{C}$ by over $50 \%$ under these conditions are listed below.

\begin{tabular}{|c|c|c|c|c|}
\hline \multirow{2}{*}{$\begin{array}{l}{ }^{14} \mathrm{C} \text {-amino acid } \\
\text { L-Alanine }\end{array}$} & \multicolumn{2}{|c|}{ Incorporation inhibited by: } & \multicolumn{2}{|c|}{ Incorporation stimulated by } \\
\hline & $\begin{array}{l}\text { L-serine } \\
\text { L-cysteine }\end{array}$ & $\begin{array}{l}59 \% \\
61 \%\end{array}$ & None & . \\
\hline L-Aspartic acid & $\begin{array}{l}\text { L-asparagine* } \\
\text { L-glutamic acid }\end{array}$ & $\begin{array}{l}75 \% \\
74 \%\end{array}$ & None & . \\
\hline L-Glutamic acid & $\begin{array}{l}\text { L-aspartic acid } \\
\text { D-glutamic acid } \\
\text { L-glutamine }\end{array}$ & $\begin{array}{l}58 \% \\
52 \% \\
70 \%\end{array}$ & None & . \\
\hline Glycine & $\begin{array}{l}\text { L-phenylalanine } \\
\text { L-arginine }\end{array}$ & $\begin{array}{l}73 \% \\
51 \%\end{array}$ & None & . \\
\hline $\begin{array}{l}\text { L-Isoleucine } \\
\text { L-Leucine }\end{array}$ & $\begin{array}{l}\text { None } \\
\text { L-isoleucine } \\
\text { DL-p-fluorophenylalanine }\end{array}$ & $\begin{array}{l}50 \% \\
76 \%\end{array}$ & $\begin{array}{l}\text { L-valine } \\
\text { L-valine }\end{array}$ & $\begin{array}{l}105 \% \\
112 \%\end{array}$ \\
\hline $\begin{array}{l}\text { L-Phenylalanine } \\
\text { L-Valine }\end{array}$ & $\begin{array}{l}\text { DL-p-fluorophenylalanine* } \\
\text { None }\end{array}$ & $95 \%$ & $\begin{array}{l}\text { None } \\
\text { L-leucine } \\
\text { L-isoleucine }\end{array}$ & $\begin{array}{l}. \\
98 \% \\
91 \%\end{array}$ \\
\hline
\end{tabular}

* In the presence of these ${ }^{12} \mathrm{C}$-amino acids, the incorporation of ${ }^{14} \mathrm{C}$ was independent of the concentration of ${ }^{14} \mathrm{C}$-amino acid.

Table 3. Distribution of ${ }^{14} C$ in the cell after the incorporation of [U-14 C-]-L-phenylalanine by Entodinium caudatum

Protozoa were incubated anaerobically for $5 \mathrm{hr}$ in salt solution containing 1000 units penicillin and $400 \mu \mathrm{g}$. neomycin sulphate $/ \mathrm{ml}$. in the presence of $240 \mu \mathrm{g}$. and $10 \mu \mathrm{C}$ [U- $\left.{ }^{14} \mathrm{C}\right]-$ $L$-phenylalanine in the presence or absence of $0.01 \mathrm{M}$-DL-p-fluorophenylalanine. After incubation the washed protozoa were broken in a Potter homogenizer and the supernatant fluid and pellet fractions separated by centrifugation. These were further fractionated as described under Methods.

Protozoa incubated with $p$-fluorophenylalanine

Cold trichloroacetic acid-soluble fraction

Ethanol-soluble protein

Lipid

Nucleic acid

Residual protein

\begin{tabular}{|c|c|c|c|}
\hline \multicolumn{4}{|c|}{ Radioactivity (counts/min.) } \\
\hline \multicolumn{2}{|c|}{$\begin{array}{c}\text { Broken cell } \\
\text { supernatant fluid }\end{array}$} & \multicolumn{2}{|c|}{$\begin{array}{l}\text { Broken cell } \\
\text { pellet }\end{array}$} \\
\hline - & + & - & + \\
\hline 600 & 350 & 350 & 100 \\
\hline 1950 & 450 & 2750 & 650 \\
\hline 50 & 0 & 0 & 50 \\
\hline 900 & 250 & 1650 & 100 \\
\hline 4300 & 250 & 6500 & 100 \\
\hline
\end{tabular}

dimensions and radio-autograms prepared. With each of the amino acids tested there was only one ${ }^{14} \mathrm{C}$ spot present and this chromatographed in the same position as a marker spot of the original ${ }^{14} \mathrm{C}$-amino acid. No evidence was found of any amino acid interconversions in any of the cell fractions examined. 
The cold TCA-soluble material in the broken cell supernatant fluid of protozoa which had incorporated ${ }^{14} \mathrm{C}$ from a group- 2 amino acid labelled with ${ }^{14} \mathrm{C}$ contained only one radioactive compound, and this was always the free amino acid with which the protozoa had been incubated. With group 1 amino acids the pool usually contained two or more radioactive compounds, but as these were present in such small quantities only a few were identified. After incubation with ${ }^{14} \mathrm{C}$-alanine the pool contained alanine and $N$-acetylalanine and after incubation with glutamic acid, glutamic acid and $\mathrm{N}$-formylglutamine were present.

Incubation of protozoa with ${ }^{14} \mathrm{C}$-L-leucine in the presence of high concentrations of salts (200\% of standard) decreased incorporation of ${ }^{14} \mathrm{C}$ into the protozoal protein by $92 \%$ and into the pool by $75 \%$ as compared with incubation in a low concentration of salts ( $50 \%$ of standard). However, the only radioactive material in the pool or the protein was still leucine after incubation in high salt concentrations.

\section{Extracellular products of amino acid metabolism}

In this section the results are for the quantity of the extracellular products formed when measured after the metabolism of tracer quantities of the amino acids by approximately $10^{6}$ protozoa suspended in $3 \mathrm{ml}$. medium for $4 \mathrm{hr}$. The results have been expressed per $100 \mu$ moles carbon incorporated into the protozoa.

Alanine. The products were acetic acid $46 \mu$ moles, $N$-acetylalanine $740 \mu$ moles and $N$-formylalanine $100 \mu$ moles. The latter two compounds were separated by chromatography in solvent $\mathbf{C}$.

Glutamic acid. Acid-volatile products, $14 \mu$ moles; $N$-formylglutamic acid, 250 $\mu$ moles; $\alpha$ - $N$-formylglutamine, $250 \mu$ moles. The quantities of $N$-formylglutamic acid and $N$-formylglutamine were very variable and even after incubation for $50 \mathrm{hr}$ were less than $5 \%$ of the ${ }^{14} \mathrm{C}$ still present as glutamic acid. The absence of $\mathrm{N}$-acetylglutamic acid was shown by chromatography in solvent $B$.

Leucine. Isovaleric acid $230 \mu$ moles. The identification of this compound is reported in the following paper (Coleman, 1967). Attempts to demonstrate the formation of ammonia during the metabolism of $0.005 \mathrm{M}-\mathrm{L}-\mathrm{leucine}$ by $10^{6}$ protozoa $/ \mathrm{ml}$. were unsuccessful; there was no increase over the basal formation on the addition of the amino acid. Since $N$-acetylated amino acids were a common product of amino acid metabolism and since leucine and $N$-acetyl-leucine were not separated by chromatography in any of the standard solvent systems used previously (Coleman, 1964b), solvent $A$ was used at $4^{\circ}$ (i.e. as solvent B) instead of $30^{\circ}$ to effect this separation. No ${ }^{14} \mathrm{C}-\mathrm{N}$-acetyl-leucine was detected after incubation of protozoa with ${ }^{14} \mathrm{C}$-leucine.

Phenylalanine. Phenylacetic acid, $140 \mu$ moles. The absence of phenylpropionic acid was shown by chromatography in solvent J. Since the protozoa used in these experiments contained bacteria (Coleman, 1962; White, 1966) it was possible that these were responsible for the formation of the fatty acids, despite the fact that penicillin and neomycin were present during the incubations. To test this possibility suspensions of intact and broken protozoa (which still contained viable bacteria) were incubated in the presence and absence of penicillin and neomycin with ${ }^{14} \mathrm{C}$-leucine, and the amount of ${ }^{14} \mathrm{C}$-volatile material produced was measured at intervals. After $6 \mathrm{hr}$ the proportion of the initial ${ }^{14} \mathrm{C}$-leucine which was rendered volatile was $3 \%$ with broken protozoa under both conditions and $11 \%$ and $22 \%$, respectively, with intact protozoa in the absence 
or presence of the antibiotics, showing that the bacteria were not responsible for the formation of volatile material from leucine.

\section{Permeability of Entodinium caudatum to amino acids}

The results quoted above for the uptake of amino acids by Entodinium caudatum suggested that the protozoa were freely permeable to all amino acids and that the uptake of amino acids of group 1 and group 2 differed only in the active part of the process. To seek further evidence for this hypothesis an attempt was made to measure the proportion of the volume of a protozoon which was readily permeable to amino acids and other small molecules, by using a method based on that of Mitchell (1953). After the standard washing procedures the protozoa were made up in a very thick suspension such that on centrifugation the packed protozoal pad was approximately half the total volume. The experiments were made in $10 \mathrm{ml}$. graduated conical centrifuge tubes, the calibrations of which had been checked at $0.2,0.5,1.0$ and $1.5 \mathrm{ml}$. Samples of $0.2 \mathrm{ml} .0 .005$ or $0.05 \mathrm{M}^{-14} \mathrm{C}$-amino acid or other compound $(1-10 \mu \mathrm{c} / \mu \mathrm{M})$ and $1.0 \mathrm{ml}$. protozoal suspension or $1.0 \mathrm{ml}$. salts solution at the experimental temperature were mixed together rapidly in these tubes and $30 \mathrm{sec}$. later the whole was centrifuged for a total time of $45 \mathrm{sec}$. on a bucket-head centrifuge (final speed equivalent to $500 \mathrm{~g}$ ). The volume of the protozoal pellet was measured and then the supernatant fluid removed and $0.1 \mathrm{ml}$. used for the estimation of ${ }^{14} \mathrm{C}$. The time between mixing and the removal of the supernatant fluid was less than $5 \mathrm{~min}$. When the experiments were done at $20^{\circ}$ the protozoa were undamaged at the end, as determined microscopically, but when they were placed at $4^{\circ}$ or $39^{\circ}$ for $5 \mathrm{~min}$. before mixing with the ${ }^{14} \mathrm{C}$-amino acid there were signs of protozoal disintegration. For this reason, the time of exposure was kept to a minimum in experiments at $4^{\circ}$ and $39^{\circ}$. Except where stated, all experiments were made at $20^{\circ}$. It was also necessary to use amino acids at at least $0.001 \mathrm{M}$ because in the presence of tracer amounts only there was sufficient incorporation of ${ }^{14} \mathrm{C}$ to invalidate the results. The results were calculated as follows. The total amount of ${ }^{14} \mathrm{C}$ added to the system in the presence or absence of protozoa was calculated from the ${ }^{14} \mathrm{C}$ present in $0.1 \mathrm{ml}$. of medium in the absence of protozoa. From this value and the amount of ${ }^{14} \mathrm{C}$ present in $0.1 \mathrm{ml}$. supernatant fluid above the protozoa, the volume of liquid available to the amino acid in the presence of protozoa was calculated. The difference between this value and the total volume of liquid gave the volume impermeable to the amino acid and this was compared with the volume of the protozoa present. The percentage of the protozoal volume impermeable to the amino acid was given by

$$
100 \times[\text { total volume }-(A / 10 B)] / \text { protozoal volume, }
$$

where, in counts/min., $A=$ total amount of ${ }^{14} \mathrm{C}$ and $B={ }^{14} \mathrm{C}$ present in $0 \cdot 1 \mathrm{ml}$. supernatant fluid in the presence of protozoa.

Under these conditions $51 \pm 16 \%$ (for 10 different batches of protozoa; range $31-72 \%$ ) of the packed cell pad volume was impermeable to L-leucine and $59 \pm 13 \%$ to L-aspartic acid. The amino acids L-alanine, L-glutamic acid, glycine, L-lysine, L-methionine and L-serine and also glucose, acetate and lactate gave similar results. In experiments with leucine the impermeable volume was not altered by halving the standard salt concentration, raising the temperature to $39^{\circ}$ or lowering it to $4^{\circ}$. When the protozoal pellets in the above experiments were resuspended in salts medium and 
the protozoa washed twice on the centrifuge, over $90 \%$ of the intracellular ${ }^{14} \mathrm{C}$ was released. When the low molecular weight compounds were replaced by ${ }^{14} \mathrm{C}-$ Escherichia coli the impermeable volume was increased to $86 \%$. Since Conway \& Downey (1950) showed theoretically that in a packed pad of spheres $26 \%$ of the total volume was inter-particulate and since Roberts et al. (1955) found $10 \%$ of intercellular water in a packed pad of $E$. coli, it is suggested that little of the protozoon was permeable to bacteria at $20^{\circ}$. However, it has been shown previously (Coleman, 1964b) that the gastric-sac volume of a protozoon as determined from the maximum number of bacteria that could be engulfed at $39^{\circ}$ was $0.8-2 \cdot 2 \times 10^{4} \mu^{3}$. The total volume of a protozoon was measured as $4 \cdot 7 \times 10^{4} \mu^{3}$ by centrifugation of a suspension containing a known number of protozoa for $5 \mathrm{~min}$. at $500 \mathrm{~g}$ and measuring the packed cell pad volume. Although this result includes the interstitial water surrounding each protozoon and is therefore too large, calculation from these results shows that the gastric sac, penetrable by Escherichia coli, when the protozoa were actively engulfing bacteria, occupied approximately $17-47 \%$ of the volume of each protozoon, i.e. the impenetrable volume was $53-83 \%$, a similar value to that obtained for amino acids. To determine whether the impenetrability of $50-60 \%$ of the protozoon was due to a permeability barrier or to the presence of solid material such as starch, the impermeable volume was measured in the presence of $500 \mu \mathrm{g}$. cetyltrimethylammonium bromide (CTAB)/ml. to break any permeability barriers and was found to be only $25 \%$ of the protozoal volume. This result agreed with the finding that $74 \%$ of the weight of a packed pad of protozoa was lost on drying in an oven at $105^{\circ}$, i.e. that $74 \%$ of the pad was water. The starch present in the protozoa occupied $15-20 \%$ of the protozoal volume as determined by centrifugation of sonically-treated protozoa for $30 \mathrm{~min}$. at $3000 \mathrm{~g}$ and measuring the volume of the white material at the bottom of the pellet. From the difference in the leucine-impermeable and CTAB-impermeable volumes it is apparent that $25 \%$ of the cell volume was not permeable to amino acids or to bacteria. Since the protozoal ectoplasm never contained engulfed $E$. coli and was separated from the endoplasm by a distinct membrane (Coleman \& Hall, 1966) it is tentatively suggested that the ectoplasm may not be permeable to amino acids in short-time experiments at $20^{\circ}$. Likewise, since ${ }^{14} \mathrm{C}$-labelled compounds were found in the cold TCA-soluble pool of protozoa which had been incubated with ${ }^{14} \mathrm{C}$-amino acids for several hours and then washed, it is apparent that compounds in some part of the protozoal cell, possibly the ectoplasm, did not rapidly diffuse into the medium.

\section{DISCUSSION}

Bryant \& Robinson (1963) showed that many pure strains of rumen bacteria utilized ammonia in preference to amino acids for growth and when provided with amino acids as sole source of nitrogen incorporated little amino acid carbon into cellular materials. Since it is not possible to grow these protozoa in the absence of bacteria (Coleman, 1962) the nitrogenous compounds essential for growth cannot be determined directly, but from the absence of any amino acid interconversions it is suggested that Entodinium caudatum probably utilizes intact amino acids rather than forming them from carbohydrate and ammonia. Lewis (1955), who used crude suspensions of rumen bacteria, showed that some amino acids were extensively broken down to fatty acids, carbon dioxide and ammonia. More recently Lewis \& Emery (1962) and 
Menahan \& Schultz (1964) showed that a common product from the metabolism of amino acids by crude rumen contents was an acid containing one carbon atom less than the parent amino acid, e.g. leucine was metabolized to isovaleric acid. The present results indicate that although $E$. caudatum catabolized amino acids very slowly the type of product was characteristic of that obtained with other rumen micro-organisms.

Although these experiments were made in the presence of antibiotics, it was possible that the intracellular bacteria, e.g. Bacterium 31 (Coleman, 1964b) which can grow with ammonia as sole nitrogen source and might therefore be expected to interconvert amino acids, might metabolize the amino acids before they could be incorporated into protozoal protein. However, the absence of any amino acid interconversions by either the broken cell supernatant fluid or the pellet fractions and of any volatile fatty acid production from leucine in the presence of broken protozoa suggest that the bacteria were of little importance under these conditions.

The results show that Entodinium caudatum has a definite but limited ability to concentrate all amino acids inside the organism. This active process, which is only important at low external concentrations, was inhibited by specific compounds (such as $p$-fluorophenylalanine on phenylalanine incorporation), was temperature-sensitive, was affected by salt concentration in the medium and had a finite maximum velocity which was dependent on the nature of the amino acid. At higher external concentrations the amino acids were taken up by a different process which was not inhibited by specific inhibitors, was less temperature-sensitive, was less affected by the salt concentration and had an almost infinite maximum velocity. The permeability studies made with thick protozoal suspensions at $20^{\circ}$, where the total ${ }^{14} \mathrm{C}$-amino acid uptake was less than $15 \%$ of that at $39^{\circ}$, probably related to this latter passive process and showed that low molecular weight compounds in the medium could freely penetrate at least the endoplasm of the organism. Presumably the amino acids slowly diffuse into the organism under all conditions and the active uptake process is superimposed on this slow movement. For the amino acids discussed in this paper the rate of passive uptake always exceeded the rate of active uptake above $0.003 \mathrm{M}$, but for glycine (Coleman, 1963) the maximum velocity of the active process was over five times that for leucine and even at $0.1 \mathrm{M}$ the active uptake was faster than the passive. It is of interest that Streptococcus faecalis (Gale, 1947) incorporated some amino acids, e.g. glutamic acid, by an active process at all concentrations, whereas lysine was taken up by a passive diffusion process at all concentrations.

Since all the measurements on the uptake of amino acids were of incorporation into the whole protozoon and since there was a comparatively small amount of ${ }^{14} \mathrm{C}$ found in the cell pool this suggests that it was the uptake mechanism that was the ratelimiting step in the passage of amino acids from the supernatant fluid into cell-protein. This barrier can be overcome by giving the amino acids as whole bacteria; it has been shown (Coleman, 1964b) that the same quantity of leucine was utilized much more economically by the protozoa when fed in the form of intact bacteria than when given as free amino acid.

I wish to thank Mr G. A. Embleton for inserting permanent rumen canulas into the sheep used to provide rumen fluid for the routine maintenance of the protozoa, the members of the Sub-Department of Chemical Microbiology, Biochemistry Department, University of Cambridge, for their helpful advice and criticism, and Miss B. Hanzl for valuable technical assistance. 


\section{REFERENCES}

ABou AkKadA, A. R. \& HowaRD, B. H. (1962). The biochemistry of rumen protozoa. 5. The nitrogen metabolism of Entodinium. Biochem. J. 82, 313.

BoreK, B. A. \& W WeLSCH, H. (1953). The enzymatic degradation of histidine. J. biol. Chem. $205,459$.

Bryant, M. P. \& Robinson, I. M. (1963). Apparent incorporation of ammonia and amino acid carbon during growth of selected species of ruminal bacteria. J. Dairy Sci. 46, 150.

Buld, H. B. (1951). Physical Biochemistry. New York: John Wiley and Sons Inc.

Coleman, G. S. (1958). Maintenance of oligotrich protozoa from the sheep rumen in vitro. Nature, Lond. 182, 1104.

Coleman, G. S. $(1960 a)$. The cultivation of sheep rumen oligotrich protozoa in vitro. J. gen. Microbiol. 22, 555.

Coleman, G. S. $(1960 \mathrm{~b})$. Effect of penicillin on the maintenance of rumen oligotrich protozoa. Nature, Lond. 187, 518.

Coleman, G. S. (1962). The preparation and survival of almost bacteria-free suspensions of the rumen ciliate Entodinium caudatum. J. gen. Microbiol. 28, 271.

Coleman, G. S. (1963). The growth and metabolism of rumen ciliate protozoa. Symp. Soc. gen. Microbiol. 13, 198.

Coleman, G. S. $(1964 a)$. The metabolism of ${ }^{14} \mathrm{C}$-glycine and ${ }^{14} \mathrm{C}$-bicarbonate by washed suspensions of the rumen ciliate Entodinium caudatum. J. gen. Microbiol. 35, 91.

Coleman, G. S. $(1964 b)$. The metabolism of Escherichia coli and other bacteria by Entodinium caudatum. J. gen. Microbiol. 37, 209.

Coleman, G. S. (1967). The metabolism of amino acids of Escherichia coli and other bacteria by the rumen ciliate Entodinium caudatum. J. gen. Microbiol. 47, 449.

Coleman, G. S. \& Hall, F. J. (1966). Bacterial feeding by the rumen ciliate Entodinium caudatum. J. gen. Microbiol. 44, iii.

Conway, E. J. \& DownEY, M. (1950). An outer metabolic region of the yeast cell. Biochem. J. 47, 347.

Davson, H. \& Danielli, J. F. (1952). The Permeability of Natural Membranes, p. 54. Cambridge University Press.

GALE, E. F. (1947). The assimilation of amino acids by bacteria. 1. The passage of certain amino acids across the cell wall and their concentration in the internal environment of Streptococcus faecalis. J. gen. Microbiol. 1, 53.

Greenstein, J. P. \& Winitz, M. (1961). Chemistry of the Amino Acids. New York: John Wiley and Sons Inc.

Guillaume, J. \& OsteuX, R. (1955). Détermination des acides aliphatiques volatils de $C_{1}$ à $C_{6}$ dans les liquids biologiques par chromatographie sur papier. C. r. Séanc. Acad. Sci., Paris, 241, 501.

GutierRez, J. \& DAvis, R. E. (1962). Culture and metabolism of the rumen ciliate Epidinium ecaudatum (Crawley). Appl. Microbiol. 10, 305.

Hardy, T. L., Holland, D. O. \& NAYleR, J. H. C. (1955). One-phase solvent mixtures for the separation of amino acids. Analyt. Chem. 27, 971.

Holter, H. (1965). Passage of particles and macromolecules through cell membranes. Symp. Soc. gen. Microbiol. 15, 89.

LEWIS, D. (1955). Amino acid metabolism in the rumen of the sheep. Br. J. Nutr. 9, 215.

LEWIS, T. R. \& EMERY, R. S. (1962). Intermediate products in the catabolism of amino acids by rumen microorganisms. J. Dairy Sci. 45, 1363.

Menahan, L. A. \& Schultz, L. H. (1964). Metabolism of leucine and valine within the rumen. $J$. Dairy Sci. 47, 1080 .

Mitchell, P. (1953). Transport of phosphate across the surface of Micrococcus pyogenes: nature of the cell inorganic phosphate. J. gen. Microbiol. 9, 273.

Roberts, R. B., Abelson, P. H., Cowie, D. B., Bolton, E. T. \& Britten, R. J. (1955). Studies on Biosynthesis in Escherichia coli. Publs Carnegie. Instn, no. 607.

TABOR, H. \& MeHLER, A. H. (1954). Isolation of $N$-formyl L-glutamic acid as an intermediate in the enzymatic degradation of L-histidine. J. biol. Chem. $210,559$.

WARNER, A. C. I. (1964). The breakdown of asparagine, glutamine and other amides by microorganisms from the sheep's rumen. Aust. J. biol. Sci. 17, 170.

White, R. W. (1966). Bacterial population of a rumen ciliate Entodinium caudatum cultured in vitro. J. gen. Microbiol. 42, xii.

Williams, P. P., Davis, R. E., Doetsch, R. N. \& Gutierrez, J. (1961). Physiological studies of the rumen protozoon Ophyroscolex caudatus (Eberlein). Appl. Microbiol. 9, 405. 